\title{
149 ASSESSMENT OF NUTRITIONAL QUALITY OF WHEAT MALT EXTRACT AND PREPARATION OF NON- CONVENTIONAL MALTED HEALTH BEVERAGES
}

Kanika Anand, ${ }^{1}$ Parul Sharma ${ }^{1}$ Department of Nutrition and Dietetics, Manav Rachna International University, Faridabad, Haryana, India; ${ }^{2}$ Department of Food Science and Nutrition, Banasthali Vidyapith, Jaipur, Rajasthan, India

10.1136/bjsm.2010.078725.149

Consumer awareness for the deleterious impact of malnutrition on health has grown in the last years. Thus leading to the increase in the demand for natural food and beverage products by health conscious consumers. The present study attempts to introduce a novel concept for the production of non-conventional health beverages based on malted wheat extract (variety used HD2733). In view of their health credentials these malted health beverages can be used as healthier alternative to conventional soft drinks and alcoholic beverages. The study involves the determination of physical characteristics of unmalted and nutrient analysis of both malted and unmalted wheat kernels of chosen varieties. Sensory acceptability of prepared malted health beverages that is, malted coffee and malted ice-cream milk shake was also evaluated at 5\%, 15\% and $20 \%$ incorporations. Physical characteristics of kernel that is, 1000 kernel weight, hectolitre weight, grain length and width were $42.4 \mathrm{~g}, 80.9 \mathrm{~kg}, 6.5 \mathrm{~mm}$ and $3.30 \mathrm{~mm}$, respectively. Malting resulted in slight increase in certain nutrients like protein content, mineral ash content, calcium and ascorbic levels, although a decrease in fat content, iron content and phytic acid levels was observed post malting. Sensory acceptability based on the overall acceptability showed malted health beverages prepared from $15 \%$ malt extract were most acceptable. Thus some modifications in the well known processes in the brewing industry would pave the way to design and produce innovative malt based health drinks. 